\title{
The Level of Brand Awareness in Consumer Electronic Products: The Example of Kazakhstan and Kyrgyzstan
}

\author{
Kutay OKTAY \\ Kastamonu University \\ Department of Tourism and Hotel \\ Management, \\ Kastamonu University, Turkey \\ koktay@kastamonu.edu.tr
}

Bilgehan GÜLCAN

Kyrgyz-Turkish Manas University, Department of Tourism and Hotel

Management, Kyrgyzstan.

Gazi University, Department of Tourism

Management, Turkey

bilgehan70@gmail.com,

\author{
Musa ÇAKIR \\ Ahmet Yesevi University, \\ Department of Business Administration, \\ Kazakhstan \\ musacakir73@hotmail.com
}

\begin{abstract}
Brand awareness which is considered as one of the most important factor affecting the consumer purchasing preferences has been investigated by both academics and practitioners in the field of marketing in recent years. The current study investigated brand awareness in Kazakhstan and Kyrgyzstan regarding consumer electronic products, such as laptop computers, tablet computers, and cell phones. To determine brand awareness, data were obtained by using suitable market analysis methods, and then analyzed by using the Spearman correlation and the chi-square test for independence. Based on the study results, it was observed that the level brand awareness was high for laptop computers and cell phones, while being comparatively lower for tablet computers.
\end{abstract}

Key words: Brand Awareness, Electronic Consumer Products, Kazakhstan, Kyrgyzstan

\section{INTRODUCTION}

The collapse of the Eastern Bloc is considered as "one of the greatest geopolitical earthquakes of the 20th century" (Caratini, 1992), and although the countries of Central Asia declared their independence soon after the dissolution of the Soviet Union, these countries encountered many difficulties before reaching any form of political stability. These difficulties were mainly related not to geographic or economic factors, but rather to the lack of a tradition of independence and selfsovereignty in the region (Reznikova, 1997, p.56). The absence of such a tradition had significant negative effects on the socio-economic structure of these countries. 
Nevertheless, the transition of these countries from a "centrally-planned economic system" to a "market economy" was supported by many developed Western countries and international financial institutions.

We live in a rapidly changing world. In the past, adapting to change was sufficient in and of itself for businesses to ensure their survival and their continued existence. Nowadays, however, selecting the correct approach when adapting to change is equally as important as the willingness and decision to adapt. Many businesses in our day consider their environment as an uncontrollable factor, and attempt to adapt by displaying a passive approach. However, numerous studies have demonstrated that businesses capable of creating brand awareness and corporate identity are more likely to be successful.

The ability of business to produce higher quality goods and services, to develop their competitive reflexes, and to continue their existence in the business world depends heavily on ensuring that their brand is perceived differently from other brands - and is thus preferred over them. The brand is of vital importance for businesses, and is a significant factor that affects the purchasing choices of consumers. As such, it is often stated that businesses produce "products," while consumers purchase "brands."

\section{BRAND AWARENESS AND ITS CHARACTERISTICS}

Brand awareness refers to the ability of consumers to recall and recognize a particular brand. This awareness positively or negatively affects the purchasing decisions of consumers. Consequently, organizations with positive brand awareness are capable of increasing their market share (Huang and Sarıgöllü, 2012, p.92; Moisescu, 2009; Bertch and Ostermann, 2011). This awareness facilitates the marketing of products and services, and is commonly used as a marketing technique (Macdonald and Sharp, 2000). According to Hombur (2010) and Woodward (2000), the increase in the market performance or share of organizations and businesses can be considered a consequence of their ability to create brand awareness. Oh (2000) similarly emphasized the effect of brand awareness on the perception of quality among consumers, and the confidence they show towards products or services. Furthermore, Aaker (1996) described that the market performance of businesses depends on their brand equity, which is one of the four main factors that constitutes brand awareness. The three other factors include brand dependence, perceived quality, and brand recall.

Brand recognition can be ensured by creating awareness among consumers. For this reason, developing a brand requires the brand to effectively influence the consumers and to take hold in their minds. Brand awareness, on the other hand, is created as a result of the information, both positive and negative, that an individual has regarding a particular brand (Valkenburg and Buijen, 2005, p.461).

Consumers show greater preference for the brands they recognize compared to the brands they do not. In case a brand is included into the set of brands/products that the consumers show interest, the preference of that particular brand over the others will depend on brand awareness. Brands that are not recognized, or have lower brand awareness, are far less likely to be preferred by customers (Gilbert, 2003: 319).

A characteristics feature of the brand is its ability to provide additional value to a product or service that satisfies certain functional and psychological demands (Crimmins, 1992, p.14). The perceived quality and confidence associated with a brand 
reflects customers' satisfaction concerning a particular product's or service's suitability for their needs (Keller, 2003). A high confidence in the quality of a brand associated with a particular product or service will allow the marketer to sell this product or service at higher prices, and also provide protection against price competition. In addition, increasing confidence towards a brand will contribute to facilitating the efforts and activities for increasing its market share (Pride and Ferrell, 1997).

\section{METHOD}

The main purpose of this study was to assess brand awareness in Kazakhstan and Kyrgyzstan, which are considered transitional economies, based on electronic consumer products. In this context, electronic products were evaluated according to three different groups, which were: (1) laptop computers, (2) tablet computers, and (3) cell phones. The aim was to determine the brands associated with the highest brand awareness in each one of these product groups, and to determine the factors that affected the preferences of the customers.

The study population consisted of consumers aged 18 and above who lived in Bishkek, the capital of Kyrgyzstan, and Almaty, the largest city of Kazakhstan. Based on data from the "Annual Demographic Report of the Kyrgyz Republic," published in 2012 by the Statistical Committee of the Kyrgyz Republic, the number of consumers aged 18 and above living in urban Bishkek was 600,982 in 2011. Based on data from the Almaty City Statistics Book published by the Agency on Statistics of the Republic of Kazakhstan published in 2011, the number of consumers aged 18 and above living in urban Almaty was 1,013,327 in 2009. Based on the 1,614,309 individuals who constituted the study population, the sample size for this study was calculated according to a $95 \%$ confidence interval and $3.22 \%$ error margin with the formula provided below (which is normally used in circumstances where the population size is above 10,000 ) (Özdamar, 2003, pp. 116-118).

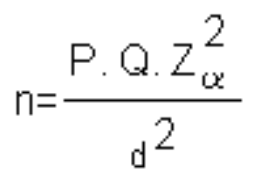

$\mathrm{n} \quad=$ Number of individuals to be included into the sample

$\mathrm{P} \quad=$ Frequency (probability) of the event being investigated $\quad \mathrm{P}=0.5$

$\mathrm{Q}=$ Probability of not observing the event being investigated (1-p) $\mathrm{Q}=0.5$

$\mathrm{Z}_{\alpha} \quad=\mathrm{Z}$ score (desired confidence interval) $\quad \mathrm{Z}_{\alpha}=1.96$

$\mathrm{d}=$ Acceptable margin of error $\quad \mathrm{d}=0.02755$

Based on the formula provided above, and according to the desired confidence interval and the acceptable margin of error, the necessary sample size for the study was determined to be 926 . Thus, the sample data set was based on 980 subjects (500 from Almaty, 480 from Bishkek).

In the questionnaires used to assess brand awareness, items using both the unaided recall and aided recall techniques were included. After developing the initial questionnaire form, a total of 50 pilot applications were performed. Questionnaire items that were determined to be unclear or difficult to understand during these pilot applications were corrected accordingly. Once the necessary corrections were 
performed on the relevant items, data collection activities commenced. The collection of data was performed between January 14, 2013 and March 2, 2014 over a period of 40 days. Among the 980 questionnaires that were completed, 51 were not included in the study evaluations due to incomplete data. As result, at total of 929 questionnaires were evaluated within the context of the study.

The data collected with the questionnaire forms were analyzed by entering the data into a computer and using the SPSS program. Cronbach's alpha test was used in the study to determine the level of confidence. Based on the results of the Cronbach's alpha test, a value of 0.626 was obtained. This value indicated that the questionnaire was within an acceptable confidence interval.

\section{Cronbach's Alpha Confidence Test Result}

\begin{tabular}{|c|c|}
\hline Cronbach's Alpha & Number of Items \\
\hline 0.626 & 43 \\
\hline
\end{tabular}

In addition, the sample Kolmogorov-Smirnov test was used to assess the normal distribution of the data set. According to the results of this test, the asymptotic significance values for all questionnaire items were determined to be less than 0.05 . As such, since the study data did not demonstrate a normal distribution, non-parametric methods instead of parametric methods were used within the context of the study.

The study data were evaluated, described, and reported by using descriptive statistics, such as frequency, percentage distribution, mean value, and standard deviation. In addition to this, the significant differences between the demographic factors and brand awareness were evaluated by using the chi-square test of independence. The relationship between the brands that first came to the mind of the subjects and the brands that they actually purchased was examined using Spearman's correlation.

\section{FINDINGS}

The demographic characteristics of the study subjects are shown in Table 1.

Table 1: Demographic Information Regarding the Study Subjects

\begin{tabular}{|l|c|c|c|c|}
\hline Gender & Frequency & Percentage & Valid Percentage & $\begin{array}{c}\text { Cumulative } \\
\text { Percentage }\end{array}$ \\
\hline Female & 500 & 53.8 & 53.8 & 53.8 \\
\hline Male & 429 & 46.2 & 46.2 & 100.0 \\
\hline Age & Frequency & Percentage & Valid Percentage & $\begin{array}{c}\text { Cumulative } \\
\text { Percentage }\end{array}$ \\
\hline $18-22$ & 221 & 23.8 & 23.8 & 23.8 \\
\hline $23-25$ & 140 & 15.1 & 15.1 & 38.9 \\
\hline $26-30$ & 140 & 15.1 & 15.1 & 53.9 \\
\hline $31-35$ & 119 & 12.8 & 12.8 & 66.7 \\
\hline $36-40$ & 114 & 12.3 & 12.3 & 89.0 \\
\hline $41-45$ & 89 & 9.6 & 9.6 & 94.9 \\
\hline $46-50$ & 59 & 6.4 & 6.4 & 97.7 \\
\hline $51-55$ & 26 & 2.8 & 2.8 & 100.0 \\
\hline Above 55 & 21 & 2.3 & 2.3 & Cumulative \\
\hline Civil Status & Frequency & Percentage & Valid Percentage & 52.5 \\
\hline Married & 488 & 52.5 & 52.5 & \\
\hline
\end{tabular}


K. Oktay - B. Gülcan - M. Çakır 7/1 (2015) 103-124

\begin{tabular}{|c|c|c|c|c|}
\hline Single & 368 & 39.6 & 39.6 & 92.1 \\
\hline Divorced & 52 & 5.6 & 5.6 & 97.7 \\
\hline Widowed & 21 & 2.3 & 2.3 & 100.0 \\
\hline Number of Children & Frequency & Percentage & Valid Percentage & $\begin{array}{l}\text { Cumulative } \\
\text { Percentage }\end{array}$ \\
\hline None & 393 & 42.3 & 42.3 & 42.3 \\
\hline 1 & 154 & 16.6 & 16.6 & 58.9 \\
\hline 2 & 142 & 15.3 & 15.3 & 74.2 \\
\hline 3 & 112 & 12.1 & 12.1 & 86.2 \\
\hline 4 & 87 & 9.4 & 9.4 & 95.6 \\
\hline 5 & 24 & 2.6 & 2.6 & 98.2 \\
\hline 6 and above & 17 & 1.8 & 1.8 & 100.0 \\
\hline Occupation & Frequency & Percentage & Valid Percentage & $\begin{array}{l}\text { Cumulative } \\
\text { Percentage }\end{array}$ \\
\hline Public sector employee & 229 & 24.7 & 24.7 & 24.7 \\
\hline Student & 220 & 23.7 & 23.7 & 48.3 \\
\hline Private sector employee & 215 & 23.1 & 23.1 & 71.5 \\
\hline Other occupations & 68 & 7.3 & 7.3 & 78.8 \\
\hline Worker & 67 & 7.2 & 7.2 & 86.0 \\
\hline Housewife & 66 & 7.1 & 7.1 & 93.1 \\
\hline Entrepreneur & 52 & 5.6 & 5.6 & 98.7 \\
\hline Farmer & 12 & 1.3 & 1.3 & 100.0 \\
\hline Education Level & Frequency & Percentage & Valid Percentage & $\begin{array}{l}\text { Cumulative } \\
\text { Percentage }\end{array}$ \\
\hline Elementary School & 7 & 0.8 & 0.8 & 0.8 \\
\hline Secondary School & 153 & 16.5 & 16.5 & 17.3 \\
\hline University & 574 & 61.8 & 62.1 & 79.4 \\
\hline Graduate & 191 & 20.6 & 20.6 & 100.0 \\
\hline Not answered & 4 & 0.4 & & \\
\hline Monthly Income (USD) & Frequency & Percentage & Valid Percentage & $\begin{array}{l}\text { Cumulative } \\
\text { Percentage }\end{array}$ \\
\hline Less than 100 & 122 & 13.1 & 14.6 & 14.6 \\
\hline $100-300$ & 233 & 25.1 & 27.8 & 42.4 \\
\hline $301-500$ & 195 & 21.0 & 23.3 & 65.6 \\
\hline $501-800$ & 99 & 10.7 & 11.8 & 77.4 \\
\hline $801-1000$ & 84 & 9.0 & 10.0 & 87.5 \\
\hline $1001-1500$ & 45 & 4.8 & 5.4 & 92.8 \\
\hline $1501-2000$ & 32 & 3.4 & 3.8 & 96.7 \\
\hline $2001-3000$ & 20 & 2.2 & 2.4 & 99.0 \\
\hline $3001-5000$ & 8 & 0.9 & 1.0 & 100.0 \\
\hline Not answered & 91 & 9.8 & & \\
\hline City of Residence & Frequency & Percentage & Valid Percentage & $\begin{array}{l}\text { Cumulative } \\
\text { Percentage }\end{array}$ \\
\hline Almaty & 500 & 53.8 & 53.8 & 53.8 \\
\hline Bishkek & 429 & 46.2 & 46.2 & 100.0 \\
\hline TOTAL & 929 & 100.0 & 100.0 & \\
\hline
\end{tabular}

During the study, the subjects were first asked to name the laptop computer, tablet computer, and cell phone brands that first came to their minds (i.e. that they best knew). The subjects were then asked to name the brands of laptop computer, tablet computer, and cell phone that they purchased or owned. Spearman's correlation analysis was performed to determine whether there was any relationship between these two variables. The results of this analysis are provided in Table 2. Based on the results obtained from the analysis, a correlation coefficient of 0.475 was calculated between the laptop computer brands that first came to mind and the laptop computer brands that 
were purchased, which indicated a positive and significant relationship. Similarly, the calculated correlation for cell phone brands was 0.107 , which also indicated a positive and significant relationship between the brands that first came to mind and the brands that were purchased. However, for tablet computers, no significant relationship was identified between the brands that first came to mind and the brands that were purchased.

With laptop computers, a positive correlation was observed between the brands that first came to mind and the brands that were actually purchased. The laptop computer brands most frequently described as the first ones to come to mind were: Samsung, Acer, Asus, and Sony; while the most frequently purchased brands were Acer, Samsung, Sony, and Apple.

With tablet computers, a positive yet weak correlation was observed between the brands that first came to mind and the brands that were actually purchased. The tablet computer brands most frequently described as the first ones to come to mind were: Samsung, Acer, Asus, and Sony; while the most frequently purchased brands were Apple, Samsung, Sony, and Asus.

Table 2: Results of the Spearman Correlation Analysis

\begin{tabular}{|c|c|c|c|c|c|c|c|}
\hline \multicolumn{2}{|c|}{ Spearman Correlation } & $\begin{array}{l}\text { Laptop } \\
\text { Computer } \\
\text { Brands that } \\
\text { first came } \\
\text { to mind } \\
\end{array}$ & $\begin{array}{l}\text { Tablet } \\
\text { Computer } \\
\text { Brands that } \\
\text { first came } \\
\text { to mind }\end{array}$ & $\begin{array}{c}\text { Cell Phone } \\
\text { Brands that } \\
\text { first came to } \\
\text { mind }\end{array}$ & $\begin{array}{l}\text { Purchased } \\
\text { Laptop } \\
\text { Computer } \\
\text { Brands }\end{array}$ & $\begin{array}{l}\text { Purchased } \\
\text { Tablet } \\
\text { Computer } \\
\text { Brands }\end{array}$ & $\begin{array}{c}\text { Purchased } \\
\text { Cell Phone } \\
\text { Brands }\end{array}$ \\
\hline $\begin{array}{l}\text { Laptop } \\
\text { Computer } \\
\text { Brands that first } \\
\text { came to mind }\end{array}$ & $\begin{array}{l}\text { Correlation } \\
\text { Coefficient } \\
\text { Sig. (2-tailed) } \\
\mathrm{N}\end{array}$ & $\begin{array}{r}1 \\
929 \\
\end{array}$ & & & & & \\
\hline $\begin{array}{l}\text { Tablet Computer } \\
\text { Brands that first } \\
\text { came to mind }\end{array}$ & $\begin{array}{l}\text { Correlation } \\
\text { Coefficient } \\
\text { Sig. (2-tailed) } \\
\mathrm{N}\end{array}$ & $\begin{array}{r}0.065 \\
0.061 \\
929\end{array}$ & $\begin{array}{r}1 \\
929 \\
\end{array}$ & & & & \\
\hline $\begin{array}{l}\text { Cell Phone } \\
\text { Brands that first } \\
\text { came to mind }\end{array}$ & $\begin{array}{l}\text { Correlation } \\
\text { Coefficient } \\
\text { Sig. (2-tailed) } \\
\mathrm{N}\end{array}$ & $\begin{array}{r}0.161(* *) \\
0 \\
929\end{array}$ & $\begin{array}{r}0.170(* *) \\
0 \\
929\end{array}$ & 1 & & & \\
\hline $\begin{array}{l}\text { Purchased } \\
\text { Laptop } \\
\text { Computer } \\
\text { Brands }\end{array}$ & $\begin{array}{l}\text { Correlation } \\
\text { Coefficient } \\
\text { Sig. (2-tailed) } \\
\mathrm{N}\end{array}$ & $\begin{array}{r}0.475(* *) \\
0 \\
929\end{array}$ & $\begin{array}{r}0.126(* *) \\
0.001 \\
929\end{array}$ & $\begin{array}{r}0.091(*) \\
0.014 \\
929\end{array}$ & 929 & & \\
\hline $\begin{array}{l}\text { Purchased Tablet } \\
\text { Computer } \\
\text { Brands }\end{array}$ & $\begin{array}{l}\text { Correlation } \\
\text { Coefficient } \\
\text { Sig. (2-tailed) } \\
\text { N }\end{array}$ & $\begin{array}{r}* 0.141(* * \\
) \\
0 \\
929\end{array}$ & $\begin{array}{r}0.04 \\
0.299 \\
929\end{array}$ & $\begin{array}{r}0.362(* *) \\
0 \\
929\end{array}$ & $\begin{array}{r}0.147(* *) \\
0 \\
929\end{array}$ & 929 & \\
\hline $\begin{array}{l}\text { Purchased Cell } \\
\text { Phone Brands }\end{array}$ & $\begin{array}{l}\text { Correlation } \\
\text { Coefficient } \\
\text { Sig. (2-tailed) } \\
\text { N }\end{array}$ & $\begin{array}{r}0.128(* *) \\
0 \\
929\end{array}$ & $\begin{array}{r}0.06 \\
0.105 \\
929\end{array}$ & $\begin{array}{r}0.107(* *) \\
0.004 \\
929\end{array}$ & $\begin{array}{r}0.136(* *) \\
0 \\
929\end{array}$ & $\begin{array}{r}0.112(* *) \\
0.004 \\
929\end{array}$ & $\begin{array}{l}1 \\
.\end{array}$ \\
\hline
\end{tabular}


K. Oktay - B. Gülcan - M. Çakır 7/1 (2015) 103-124

Table 3: The Ratios of the Laptop Computer, Tablet Computers, and Cell Phone Brands that First Came to Mind and Which Are Actually Purchased

\begin{tabular}{|c|c|c|c|c|c|c|c|c|c|c|c|}
\hline \multicolumn{2}{|c|}{$\begin{array}{l}\text { Laptop Computer } \\
\text { Brands that first } \\
\text { came to mind }\end{array}$} & \multicolumn{2}{|c|}{$\begin{array}{l}\text { Purchased Laptop } \\
\text { Computer Brands }\end{array}$} & \multicolumn{2}{|c|}{$\begin{array}{l}\text { Tablet Computer } \\
\text { Brands that first } \\
\text { came to mind }\end{array}$} & \multicolumn{2}{|c|}{$\begin{array}{l}\text { Purchased Tablet } \\
\text { Computer Brands }\end{array}$} & \multicolumn{2}{|c|}{$\begin{array}{l}\text { Cell Phone } \\
\text { Brands that first } \\
\text { came to mind }\end{array}$} & \multicolumn{2}{|c|}{$\begin{array}{c}\text { Purchased Cell } \\
\text { Phone } \\
\text { Brands }\end{array}$} \\
\hline & $\begin{array}{c}\text { Ratio } \\
(\%)\end{array}$ & & $\begin{array}{c}\text { Ratio } \\
(\%)\end{array}$ & & $\begin{array}{c}\text { Ratio } \\
(\%)\end{array}$ & & $\begin{array}{c}\text { Ratio } \\
(\%)\end{array}$ & & $\begin{array}{c}\text { Ratio } \\
(\%)\end{array}$ & & $\begin{array}{c}\text { Ratio } \\
(\%)\end{array}$ \\
\hline Samsung & 17.54 & Acer & 12.59 & Samsung & 11.41 & Apple & 22.39 & LG & 22.8 & Nokia & 41.55 \\
\hline Acer & 16.57 & Samsung & 10.65 & Acer & 11.09 & Samsung & 11.63 & Samsung & 21.3 & Samsung & 12.70 \\
\hline Asus & 9.25 & Sony & 10.11 & Asus & 10.87 & Sony & 8.29 & HTC & 7.4 & Sony & 6.03 \\
\hline Sony & 8.71 & Apple & 9.47 & Sony & 9.04 & Asus & 6.24 & Sony & 6.6 & Apple & 4.95 \\
\hline Apple & 7.96 & Asus & 8.28 & Apple & 7.97 & Acer & 5.71 & Apple & 6.2 & LG & 4.84 \\
\hline Dell & 7.31 & $\mathrm{H} \& \mathrm{P}$ & 6.45 & Toshiba & 7.53 & Lenovo & 3.66 & Blackberry & 4.2 & Motorola & 4.20 \\
\hline $\mathrm{H} \& \mathrm{P}$ & 6.56 & Dell & 6.35 & Dell & 6.03 & Dell & 3.44 & Nokia & 3.8 & HTC & 2.69 \\
\hline Toshiba & 5.92 & Lenovo & 5.48 & Lenovo & 5.71 & Toshiba & 2.91 & Motorola & 3.4 & Fly & 2.37 \\
\hline Lenovo & 4.84 & Toshiba & 5.48 & $\mathrm{H} \& \mathrm{P}$ & 5.27 & $\mathrm{H} \& \mathrm{P}$ & 2.58 & Vertu & 2.0 & Philips & 2.26 \\
\hline Panasonic & 3.65 & Compaq & 2.26 & Panasonic & 3.44 & Panasonic & 2.26 & Alcatel & 1.8 & Alcatel & 1.72 \\
\hline Compaq & 1.93 & Panasonic & 2.04 & Fijutsu & 2.80 & Packard be & 1.72 & Fly & 1.5 & Vertu & 1.51 \\
\hline Fijutsu & 1.61 & Packard bell & 1.29 & Compaq & 1.61 & Compaq & 1.18 & Philips & 1.4 & $\begin{array}{l}\text { Blackberr } \\
\mathrm{y}\end{array}$ & 1.40 \\
\hline LG & 0.86 & Others & 1.18 & LG & 1.61 & Fijutsu & 1.18 & Acer & 1.0 & Voxtel & 0.75 \\
\hline Packard bell & 0.75 & Fijutsu & 1.18 & Packard be & 1.51 & LG & 0.43 & Voxtel & 0.4 & Other & 0.32 \\
\hline E-machines & 0.53 & E-machines & 0.43 & Eurocom & 0.97 & Other & 0.11 & Other & 0.3 & & \\
\hline Other & 0.43 & LG & 0.32 & MSI & 0.97 & MSI & 0.11 & Ntc & 0.1 & & \\
\hline MSI & 0.43 & MSI & 0.21 & Other & 0.65 & & & & & & \\
\hline & & & & E-machine & 0.43 & & & & & & \\
\hline Total & 94.94 & Total & 83.85 & Total & 88.91 & Total & 73.84 & Total & 84.93 & Total & 87.30 \\
\hline System & 5.05 & System & 16.14 & System & 11.09 & System & 26.16 & System & 15.07 & System & 12.70 \\
\hline Final Total & 100 & Final Total & 100 & Final Total & 100 & Final Total & 100 & Final Total & 100 & Final Total & 100.00 \\
\hline
\end{tabular}

With cell phones, no positive correlation was observed between the brands that first came to mind and the brands that were actually purchased. The brands most frequently described as the first ones to come to mind were: LG, Samsung, HTC, and Sony; while the most frequently purchased brands were Nokia, Samsung, Sony, and Apple.

Awareness of a product or the ability to bring it to mind has often been considered an important determinant of choice. Practitioners and consumer researchers alike have been interested in indicators of memorability, since brand recall may play an important role in determining whether a product is considered for purchase at all. Various standard measures, such as aided and unaided brand name recall and top-ofmind awareness, rest on the assumption that the ability of the consumer to remember a brand or product will strongly affect the probability of its being considered for purchase (Nedungadi and Hutchinson, 1985). While our research finding about laptop computers and tablets are supporting this suggestion, findings about cell phones show no positive 
correlation between brand recall and purchasing decision. It may be reason that, other factors such as price, trends and durability may influence the purchasing decision of cell phones. Thus, beside strengthening brand strategy companies should also put emphasis other factors in their marketing activities.

The chi-square test of independence was used to examine whether there were any differences in opinions regarding recognition, reliability, quality, guarantee, durability, functionality, and price with respect to different demographic characteristics. The results of this test are shown in the tables below, with numbers written in bold indicating statistical significance $(\mathrm{p} \leq 0.05)$.

Table 4: Results of the Chi-Square Test of Independence with Respect to Gender

\begin{tabular}{|l|c|c|c|}
\hline & \multicolumn{3}{|c|}{ Gender (Pearson's Chi-Square) } \\
\hline & $\begin{array}{c}\text { Laptop } \\
\text { Computer }\end{array}$ & $\begin{array}{c}\text { Tablet } \\
\text { Computer }\end{array}$ & Cell Phone \\
\hline Recognition & 0.087 & 0.134 & 0.342 \\
\hline Reliability & 0.234 & 0.870 & 0.098 \\
\hline Quality & 0.436 & 0.098 & $\mathbf{0 . 0 3 7}$ \\
\hline Guarantee & 0.098 & 0.067 & $\mathbf{0 . 0 1 4}$ \\
\hline Durability & 0.694 & 0.089 & 0.546 \\
\hline Functionality & 0.065 & 0.237 & 0.647 \\
\hline Price & $\mathbf{0 . 0 0 0}$ & $\mathbf{0 . 0 0 0}$ & $\mathbf{0 . 0 0 0}$ \\
\hline
\end{tabular}

There was no statistical significance according to gender (i.e. between men and women) regarding the views on recognition, reliability, durability, and functionality, with more than $50 \%$ of participants in both genders considering these characteristics as very important.

However, while $80 \%$ of the male participants considered quality in cell phones as very important, $58 \%$ of female participants considered it as very important. The ratio of female participants who considered quality in cell phones as unimportant was $5 \%$, and the ratio of those who were undecided about the importance of quality in cell phones was $8 \%$.

In addition, $63 \%$ of male participants considered guarantee in cell phones as very important, while $48 \%$ of female participants considered it as very important. The difference in opinion regarding the price of laptop computers, tablet computers, and cell phones with respect to gender was clear and statistically significant. Male participants were not as concerned about product price as female participants, which indicated that women placed more importance on price than men.

Males and females want different products and they are likely to have different ways of thinking about obtaining these (Mitchell and Walsh, 2004). This diversification may vary on different products. Our research findings show that price is the most important factor which effects the purchasing decision of different genders in electronic consumer goods. It may be the reason men put more emphasis on the quality and guarantee. Findings about the relation between gender and quality and gender and 
guarantee also justify this suggestion. From this point of view retailers of electronic goods may offer more reasonable prices to their female prospects in Central Asia.

Statistically significant differences were observed between the different occupational groups regarding their views on recognition in cell phones and tablet computers, while the differences regarding recognition in laptop computers were not significant. Among all occupational groups, an average of $38 \%$ considered recognition to be very important for laptop computers. Statistically significant differences were identified in recognition with respect to occupation; for instance, while workers, farmers, and housewives accorded little importance to recognition in tablet computers, other occupational groups considered recognition in tablet computers to be more important. Also, while recognition was not considered as very important for cell phones among workers, farmers, and entrepreneurs, the other occupational groups considered recognition in cell phones to be more important.

Table 5: Results of the Chi-Square Test of Independence with Respect to Occupation

\begin{tabular}{|l|c|c|c|}
\hline & \multicolumn{3}{|c|}{ Occupation (Pearson's Chi-Square) } \\
\hline & $\begin{array}{c}\text { Laptop } \\
\text { Computer }\end{array}$ & $\begin{array}{c}\text { Tablet } \\
\text { Computer }\end{array}$ & Cell Phone \\
\hline Recognition & 0.352 & $\mathbf{0 . 0 1 4}$ & $\mathbf{0 . 0 0 4}$ \\
\hline Reliability & $\mathbf{0 . 0 2 0}$ & $\mathbf{0 . 0 4 8}$ & 0.298 \\
\hline Quality & $\mathbf{0 . 0 0 0}$ & $\mathbf{0 . 0 2 4}$ & $\mathbf{0 . 0 0 0}$ \\
\hline Guarantee & 0.078 & 0.096 & 0.364 \\
\hline Durability & 0.093 & $\mathbf{0 . 0 3 7}$ & 0.108 \\
\hline Functionality & 0.284 & $\mathbf{0 . 0 0 1}$ & 0.079 \\
\hline Price & $\mathbf{0 . 0 0 0}$ & $\mathbf{0 . 0 0 1}$ & $\mathbf{0 . 0 1 6}$ \\
\hline
\end{tabular}

Statistically significant differences were observed between the different occupational groups regarding their views on reliability in laptop computers and tablet computers, while the differences regarding reliability in cell phones were not significant. Workers and housewives accorded little importance to reliability in laptop computers; while workers, housewives and private sector employees accorded little importance to reliability in tablet computers. On the other hand, the other occupational groups accorded considerable importance to reliability in laptop computers and tablet computers. In addition, nearly of 59\% subjects from all occupational groups considered reliability in cell phones as very important.

Statistically significant differences were observed between the different occupational groups regarding their views on quality in all of the products. With respect to occupation, entrepreneurs and public sector employees considered quality to be very important in laptop computers, tablet computers, and cell phones; while private sector employees, workers, and housewives accorded little importance to quality in these products. 
No statistically significant differences were observed between the different occupational groups regarding their views on guarantee in all of the products. In all occupational groups, the ratio of subjects who considered guarantee to be very important in laptop computers, tablet computers, and cell phones was $53 \%, 54 \%$, and $66 \%$, respectively.

Statistically significant differences were observed between the different occupational groups regarding their views on durability in tablet computers, while the differences regarding durability in laptop computers and cell phones were not significant. Public sector workers, students, and workers accorded less importance to durability in laptop computers than the other occupational groups. Durability in tablet computers had little importance for housewives and workers, while other occupational groups considered durability in tablet computers as very important. All occupational groups considered durability in cell phones as very important.

Statistically significant differences were observed between the different occupational groups regarding their views on functionality in tablet computers, while differences regarding functionality in laptop computers and cell phones were not significant. Public sector workers, students and workers accorded less importance to functionality in laptop computers than the other occupational groups. Functionality in tablet computers had little importance for housewives and workers, while other occupational groups considered functionality in tablet computers as very important. All occupational groups considered functionality in cell phones as very important.

Statistically significant differences were observed between the different occupational groups regarding their views on price in all of the product groups. Farmers and housewives considered price to be very important in all three product groups; while entrepreneurs, public sector workers, students, and private sector workers accorded less importance to price in these products.

A person's occupation affects the goods and services bought. Marketers try to identify the occupational groups that have an above-average interest in their products and services. A company can even specialize in making products needed by a given occupational group (Durmaz and Jablonsk, 2012). Occupation may be a more meaningful criterion than income in segmenting some markets. Truck drivers and auto mechanics may earn as much as young retailing executives or college professors. But, the buying patterns of the first two are likely to be different from the second two because of attitudes and interests. Education, occupation and income tend to be closely correlated in almost a cause-effect relationship. High-level occupations that produce high incomes usually require advanced educational training (Madhavan and Kumar, 2014). According to our research findings it is obvious that the occupation is one of the main demographic factor which influences the buying decision of consumers. Especially, factors effecting the purchasing decision of consumers in tablet computers have a significant diversification in different occupation groups. The aim of using these devices may vary according to occupation and it may cause this result. Hence companies should develop and offer different features and benefits for different occupation groups. 
K. Oktay - B. Gülcan - M. Çakır 7/1 (2015) 103-124

Table 6: Results of the Chi-Square Test of Independence with Respect to Age

\begin{tabular}{|l|c|c|c|}
\hline & \multicolumn{3}{|c|}{ Age (Pearson's Chi-Square) } \\
\hline & $\begin{array}{c}\text { Laptop } \\
\text { Computer }\end{array}$ & $\begin{array}{c}\text { Tablet } \\
\text { Computer }\end{array}$ & Cell Phone \\
\hline Recognition & 0.175 & 0.143 & 0.160 \\
\hline Reliability & 0.068 & 0.043 & $\mathbf{0 . 0 1 5}$ \\
\hline Quality & 0.208 & 0.386 & 0.249 \\
\hline Guarantee & 0.375 & 0.736 & 0.358 \\
\hline Durability & $\mathbf{0 . 0 0 5}$ & 0.083 & 0.469 \\
\hline Functionality & $\mathbf{0 . 0 0 0}$ & $\mathbf{0 . 0 0 0}$ & 0.312 \\
\hline Price & 0.763 & 0.295 & 0.163 \\
\hline
\end{tabular}

With respect to recognition in all of the product groups, no significant differences were observed between the different age groups. In all age groups, the ratio of subjects who considered recognition to be very important in laptop computers, tablet computers, and cell phones was $43 \%, 41 \%$, and $42 \%$, respectively.

Statistically significant differences were observed between the different age groups regarding their views on reliability in cell phones, while the differences regarding reliability in laptop computers and tablet computers were not significant. For cell phones, $45 \%$ of subjects between the ages of 51-55 considered reliability to be very important, while more than $60 \%$ of subjects in all the other age groups considered reliability to be very important. No significant differences were observed between different age groups with regards to the importance accorded to reliability in laptop computers and tablet computers. As such, 54\% of subjects from all age groups described reliability as being important for laptop computers, while $53 \%$ described it as being important for tablet computers.

With respect to quality in all of the product groups, no significant differences were observed between the different age groups. In all age groups, the ratios of the subjects who considered quality to be very important in laptop computers, tablet computers, and cell phones were $74 \%, 70 \%$, and $72 \%$ respectively.

With respect to guarantee, no significant differences were observed between the different age groups. In all age groups, the ratio of the subjects who considered guarantee to be important in laptop computers, tablet computers, and cell phones was $53 \%, 50 \%$, and $54 \%$, respectively.

Statistically significant differences were observed between the different age groups regarding their views on durability in laptop computers, while the differences regarding durability in tablet computers and cell phones were not significant. For laptop computers, $55 \%$ of subjects between the ages of $36-40,51 \%$ of subjects between the ages of $40-45$, and more than $70 \%$ of subjects in all of the other age groups considered durability to be very important. No significant differences were observed between different age groups regarding the importance accorded to durability in tablet computers and cell phones. As such, $61 \%$ of subjects from all age groups described durability as 
being important for tablet computers, while $65 \%$ described it as being important for cell phones.

Statistically significant differences were observed between the groups regarding their views on functionality in laptop computers and tablet computers, while the differences regarding functionality in cell phones were not significant. For laptop computers, $72 \%$ of subjects between the ages of $23-25$ considered functionality to be very important. A decrease was observed in this ratio with increasing age, which reached $42 \%$ for subjects aged 50 years and above. For tablet computers, functionality was important for $69 \%$ of subjects between the ages of $18-20$. A decrease was observed in this ratio with increasing age, which reached $39 \%$ for subjects aged 50 years and above. No significant differences were observed between different age groups with respect to the importance accorded to functionality in cell phones. As such, $65 \%$ of subjects from all age groups described functionality as being important for cell phones.

With respect to price, no significant differences were observed between the different age groups. In all age groups, the ratio of subjects who considered price to be very important in laptop computers, tablet computers, and cell phones was $40 \%, 42 \%$, and $45 \%$, respectively.

With respect to recognition, no significant differences were observed between the groups with different civil status. In all civil status groups, the ratios of subjects who considered recognition to be very important in laptop computers, tablet computers, and cell phones were $43 \%, 43 \%$, and $51 \%$ respectively.

Statistically significant differences were observed between the groups with different civil status regarding their views on reliability in laptop computers, while the differences regarding reliability in tablet computers and cell phones were not significant. For laptop computers, 53\% of married subjects considered reliability to be very important, while nearly $35 \%$ of subjects from the other civil status groups considered reliability to be very important. No significant difference was observed between the groups with respect to the importance accorded to reliability in tablet computers and cell phones. As such, 53\% of subjects from all civil status groups described reliability as being important for tablet computers, while $59 \%$ described it as being important for cell phones.

Age and life-cycle have potential impact on the consumer buying behavior. It is obvious that the consumers change the purchase of goods and services with the passage of time. Family life-cycle consists of different stages such young singles, married couples, unmarried couples etc which help marketers to develop appropriate products for each stage (Shah, 2010). In our research we didn't find many differences between age groups and factors influencing purchasing decision of electronic goods. Functionality has different importance for different age groups for laptop and tablet computers. Especially young age groups see functionality as a very important factor. This may be the because of they need more function to use their devices performing different functions. Retailers may highlight different functions of electronic devices for different age groups in order to attract them. 
K. Oktay - B. Gülcan - M. Çakır 7/1 (2015) 103-124

Table 7: Results of the Chi-Square Test of Independence with Respect to Civil Status

\begin{tabular}{|l|c|c|c|}
\hline & \multicolumn{3}{|c|}{ Civil Status (Pearson's Chi-Square) } \\
\hline & $\begin{array}{c}\text { Laptop } \\
\text { Computer }\end{array}$ & $\begin{array}{c}\text { Tablet } \\
\text { Computer }\end{array}$ & Cell Phone \\
\hline Recognition & 0.245 & 0.321 & 0.165 \\
\hline Reliability & $\mathbf{0 . 0 0 1}$ & 0.465 & 0.478 \\
\hline Quality & 0.084 & 0.365 & $\mathbf{0 . 0 0 2}$ \\
\hline Guarantee & $\mathbf{0 . 0 3 8}$ & 0.089 & 0.073 \\
\hline Durability & 0.290 & 0.278 & 0.476 \\
\hline Functionality & $\mathbf{0 . 0 0 0}$ & $\mathbf{0 . 0 0 1}$ & 0.759 \\
\hline Price & 0.475 & 0.639 & 0.238 \\
\hline
\end{tabular}

Statistically significant differences were observed between the different groups regarding their views on quality in cell phones, while the differences regarding quality in laptop computers and tablet computers were not significant. For cell phones, $35 \%$ of single subjects considered quality to be very important, while nearly $72 \%$ of subjects from the other civil status groups considered quality to be very important. No significant difference was observed between the different groups with respect to the importance accorded to quality in laptop computers and tablet computers. As such, 74\% of subjects from all age groups described quality as being important for laptop computers, while $70 \%$ described it as being important for tablet computers.

Statistically significant differences were observed between the groups with different civil status regarding their views on guarantee in laptop computers, while the differences regarding guarantee in tablet computers and cell phones were not significant. For laptop computers, $56 \%$ of married and single subjects considered guarantee to be very important, while nearly $42 \%$ of subjects from the other civil status groups considered guarantee to be very important. No significant difference was observed between the different groups with respect to the importance accorded to guarantee in tablet computers and cell phones. As such, 53\% of subjects from all civil status groups described warranty as being important for tablet computers, while $60 \%$ described it as being important for tablet computers.

With respect to durability, no significant differences were observed between the groups with different civil status. In all civil status groups, the ratios of subjects who considered durability to be very important in laptop computers, tablet computers and cell phones were $63 \%, 60 \%$, and $65 \%$, respectively.

Statistically significant differences were observed between the groups with different civil status regarding their views on functionality in laptop computers and tablet computers, while the differences regarding functionality in cell phones were not significant. For laptop computers, $65 \%$ of married and single subjects considered functionality to be very important, while nearly $40 \%$ of subjects from the other civil status groups considered functionality to be very important. For tablet computers, $68 \%$ of single subjects considered functionality to be very important, while nearly $45 \%$ of 
subjects from the other civil status groups considered functionality to be very important. No significant difference was observed between the groups with different civil status with respect to the importance accorded to functionality in cell phones. As such, $67 \%$ of subjects from all civil status groups described functionality as being important for cell phones.

With respect to price, no statistically significant differences were observed between the groups with different civil status. In all civil status groups, the ratios of the subjects who considered price to be very important in laptop computers, tablet computers, and cell phones was $40 \%, 42 \%$, and $48 \%$, respectively.

Consumer behaviour is influenced not only by consumer personalities and motivations, but also by the relationships within families (family is a familiar social unit). In a family, members must satisfy their individual and shared needs by drawing on a common and shared, relatively fixed supply of sources. The individual family is a strong, most immediate and most pervasive influence on decision-making. The husband, wife and children influence each other and are influenced by others (Durmaz and Jablonsk, 2012). Our research findings show that, functionality of laptop and tablets computers have the most variable results for different civil status groups. Different civil status groups may seek for various functions of laptop and tablet computers and it may cause this result. Generally other factors influencing purchasing decisions of electronic goods do not vary too much depending on the civil status of the consumers. Hence manufacturers and retailers of electronic goods should consider the civil status of their prospects especially regarding functionality of their devices.

Table 8: Results of the Chi-Square Test of Independence with Respect to the Number of Children

\begin{tabular}{|l|c|c|c|}
\hline & \multicolumn{3}{|c|}{ Number of Children (Pearson's Chi-Square) } \\
\hline & $\begin{array}{c}\text { Laptop } \\
\text { Computer }\end{array}$ & $\begin{array}{c}\text { Tablet } \\
\text { Computer }\end{array}$ & Cell Phone \\
\hline Recognition & $\mathbf{0 . 0 0 0}$ & $\mathbf{0 . 0 0 0}$ & $\mathbf{0 . 0 0 8}$ \\
\hline Reliability & $\mathbf{0 . 0 0 1}$ & $\mathbf{0 . 0 0 1}$ & 0.389 \\
\hline Quality & $\mathbf{0 . 0 0 0}$ & $\mathbf{0 . 0 0 7}$ & $\mathbf{0 . 0 1 6}$ \\
\hline Guarantee & $\mathbf{0 . 0 2 6}$ & 0.084 & 0.482 \\
\hline Durability & 0.254 & 0.307 & 0.093 \\
\hline Functionality & $\mathbf{0 . 0 0 0}$ & $\mathbf{0 . 0 0 0}$ & $\mathbf{0 . 0 0 1}$ \\
\hline Price & $\mathbf{0 . 0 1 7}$ & $\mathbf{0 . 0 0 0}$ & $\mathbf{0 . 0 1 1}$ \\
\hline
\end{tabular}

Statistically significant differences were observed between the groups with different numbers of children regarding their views on recognition in all of the product groups. The importance accorded to recognition in laptop computers, tablet computers, and cell phones decreased, parallel to an increase in the number of children.

Statistically significant differences were observed between the groups regarding their views on reliability in laptop computers and tablet computers, while the differences in reliability and guarantee in cell phones were not significant. For laptop 
computers, reliability became less important, parallel to an increase in the number of children. For tablet computers, reliability also became less important parallel to an increase in the number of children. No significant difference was observed between groups with different numbers of children with respect to the importance accorded to reliability in cell phones. As such, 55\% of subjects from all groups described reliability as being important for cell phones.

Statistically significant differences were observed between the groups with different numbers of children regarding their views on quality in all of the product groups. The importance accorded to quality in laptop computers, tablet computers, and cell phones decreased parallel to an increase in the number of children.

Statistically significant differences were observed between the groups with different numbers of children regarding their views on guarantee in laptop computers, while the differences regarding guarantee in tablet computers and cell phones were not significant. For laptop computers, the importance of guarantee decreased in families with four or more children. No significant difference was observed between the different groups with respect to the importance they accorded to guarantee in tablet computers and cell phones. As such, 53\% of subjects in all of the groups with different numbers of children described guarantee as being important for tablet computers, while $60 \%$ described it as being important for cell phones.

With respect to durability, no significant differences were observed between the different groups. In all groups with different numbers of children, subjects who considered durability to be very important in laptop computers, tablet computers, and cell phones was $63 \%, 60 \%$, and $65 \%$ respectively.

Statistically significant differences were observed between the groups regarding their views on functionality in all of the product groups. The importance accorded to functionality in laptop computers, tablet computers, and cell phones decreased parallel to an increase in the number of children.

Statistically significant differences were observed between the groups regarding their views on price in all of the product groups. The importance accorded to price in laptop computers, tablet computers and cell phones increased parallel to an increase in the number of children.

Children also play a huge role in influencing the family buying decisions. There are number of research findings that indicate children have significant influence in purchasing the products for which there are the primary consumers such as toys, food, clothes and school supplies (Nagarkoti, 2009). In our research we also saw that the number of children plays an important role on the buying decision of consumers. This may be the result that, families consider their children's needs and choices when purchasing these kinds of electronic goods. Because children are also considered as one of the main users of these products. 
K. Oktay - B. Gülcan - M. Çakır 7/1 (2015) 103-124

Table 9: Results of the Chi-Square Test of Independence with Respect to Monthly Income

\begin{tabular}{|l|c|c|c|}
\hline & \multicolumn{3}{|c|}{ Monthly Income (Pearson's Chi-Square) } \\
\hline & $\begin{array}{c}\text { Laptop } \\
\text { Computer }\end{array}$ & $\begin{array}{c}\text { Tablet } \\
\text { Computer }\end{array}$ & Cell Phone \\
\hline Recognition & 0.653 & 0.523 & $\mathbf{0 . 0 0 4}$ \\
\hline Reliability & $\mathbf{0 . 0 0 5}$ & $\mathbf{0 . 0 1 6}$ & $\mathbf{0 . 0 0 0}$ \\
\hline Quality & $\mathbf{0 . 0 0 0}$ & $\mathbf{0 . 0 0 0}$ & $\mathbf{0 . 0 0 0}$ \\
\hline Guarantee & $\mathbf{0 . 0 0 0}$ & $\mathbf{0 . 0 0 0}$ & $\mathbf{0 . 0 0 0}$ \\
\hline Durability & $\mathbf{0 . 0 0 0}$ & $\mathbf{0 . 0 0 0}$ & $\mathbf{0 . 0 0 0}$ \\
\hline Functionality & $\mathbf{0 . 0 0 0}$ & $\mathbf{0 . 0 0 0}$ & $\mathbf{0 . 0 0 0}$ \\
\hline Price & $\mathbf{0 . 0 0 0}$ & $\mathbf{0 . 0 0 0}$ & $\mathbf{0 . 0 0 0}$ \\
\hline
\end{tabular}

Statistically significant differences were observed between the groups with different income levels regarding their views on recognition in cell phones, while the differences regarding recognition in laptop computers and tablet computers were not significant. For cell phones, the importance accorded to recognition decreased parallel to an increase in the level of monthly income. No significant difference was observed between the groups with different income levels with respect to the importance accorded to quality for laptop computers and tablet computers. As such, 38\% of subjects from all of the groups described quality as being very important for laptop computers, while $42 \%$ described it as being very important for tablet computers.

Statistically significant differences were observed between the groups regarding their views on reliability in all of the three product groups. For laptop computers, the importance accorded to reliability gradually decreased in groups with monthly incomes between $\$ 100$ and $\$ 1000$, while the importance accorded to reliability gradually increased in groups with monthly incomes between $\$ 1000$ and $\$ 5000$. For tablet computers, the importance accorded to reliability gradually decreased in groups with monthly incomes between $\$ 100$ and $\$ 1000$, while the importance accorded to reliability gradually increased in groups with monthly incomes between $\$ 1000$ and $\$ 5000$. For cells phones, the importance accorded to reliability gradually decreased in groups with monthly incomes between $\$ 100$ and $\$ 1000$, while the importance accorded to reliability gradually increased in groups with monthly incomes between $\$ 1000$ and $\$ 5000$.

Statistically significant differences were observed between the groups with different income levels regarding their views on quality in all of the three product groups. For laptop computers, the importance accorded to quality gradually decreased in groups with monthly incomes between $\$ 100$ and $\$ 1000$, while the importance accorded to quality gradually increased in groups with monthly incomes between $\$ 1000$ and $\$ 5000$. For tablet computers, the importance accorded to quality gradually decreased in groups with monthly incomes between $\$ 100$ and $\$ 1000$, while the importance accorded to quality gradually increased in groups with monthly incomes between $\$ 1000$ and $\$ 5000$. For cell phones, the importance accorded to quality gradually decreased in groups with monthly incomes between $\$ 100$ and $\$ 1000$, while the importance accorded 
to quality gradually increased in groups with monthly incomes between $\$ 1000$ and $\$ 5000$.

Statistically significant differences were observed between groups with different income levels regarding their views on guarantee in all of the three product groups. For laptop computers, the importance accorded to guarantee gradually decreased in groups with monthly incomes between $\$ 100$ and $\$ 1000$; gradually increased in groups with monthly incomes between $\$ 1000$ and $\$ 3000$; and suddenly decreased in groups with monthly incomes between $\$ 3000$ and $\$ 5000$. For tablet computers, the importance accorded to guarantee gradually decreased in groups with monthly incomes between $\$ 100$ and $\$ 1000$; gradually increased in groups with monthly incomes between $\$ 1000$ and $\$ 3000$; and suddenly decreased in groups with monthly incomes between $\$ 3000$ and $\$ 5000$. For tablet computers, the importance accorded to quality gradually decreased in groups with monthly incomes between $\$ 100$ and $\$ 1000$; gradually increased in groups with monthly incomes between $\$ 1000$ and $\$ 3000$; and suddenly decreased in groups with monthly incomes between $\$ 3000$ and $\$ 5000$.

Statistically significant differences were observed between the groups with different income levels regarding their views on durability in all of the three product groups. For laptop computers, tablet computers, and cell phones, the importance accorded to durability gradually decreased in groups with monthly incomes between $\$ 100$ and $\$ 1000$, while the importance accorded to durability gradually increased in groups with monthly incomes above $\$ 1000$.

Statistically significant differences were observed between the groups with different income levels regarding their views on functionality in all of the three product groups. For laptop computers, tablet computers, and cell phones, the importance accorded to functionality gradually decreased in groups with monthly incomes between $\$ 100$ and $\$ 1000$, while the importance accorded to functionality gradually increased in groups with monthly incomes above $\$ 1000$.

With respect to price, statistically significant differences were identified between the different income groups in all of the three product groups. The importance accorded to price in laptop computers, tablet computers, and cell phones decreased parallel to the increase in monthly income.

The economic theory is of the view that the consumers' behavior is significantly driven by the level of income. While making a purchase the purchasing power is taken as a significant element. In contrast to this attribution the Marketing philosophy argues that the level of income cannot be treated as a single factor while explaining the consumer buying behavior and response toward a specific category. The marketing theory suggests that there might be many other potential determinants of consumer behavior toward buying different products (Wahed and others, 2014). Our survey results indicate that the income level is one of the most important variable in which its groups diverse from in each other. While price is important for low income level groups, the importance of other factor increase for high income level groups. These result can easily be explained by the income elasticity demand theory in economics. Thus, while high income groups should be attracted by factors such as quality and functionality, lower income groups can be attracted by price.

Statistically significant differences were observed between the groups with different education levels regarding their views on recognition in all of the three product 
types. The importance accorded to recognition in laptop computers, tablet computers, and cell phones decreased parallel to an increase in the level of education.

Statistically significant differences were observed between the groups regarding their views on reliability in laptop computers and tablet computers, while the differences regarding reliability in cell phones were not significant. For laptop computers, the importance accorded to reliability decreased from $85 \%$ to $44 \%$ parallel to the increase in the education level. For tablet computers, the importance accorded to reliability increased from $16 \%$ to $61 \%$ parallel to the increase in the education level. No significant differences were observed between the groups with different education levels with respect to the importance accorded to reliability in cell phones. As such, $59 \%$ of subjects from all groups described reliability as being important for cell phones.

Table 10: Results of the Chi-Square Test of Independence with Respect to Education Level

\begin{tabular}{|l|c|c|c|}
\hline & \multicolumn{3}{|c|}{ Education Level (Pearson's Chi-Square) } \\
\hline & $\begin{array}{c}\text { Laptop } \\
\text { Computer }\end{array}$ & $\begin{array}{c}\text { Tablet } \\
\text { Computer }\end{array}$ & Cell Phone \\
\hline Recognition & $\mathbf{0 . 0 4 0}$ & $\mathbf{0 . 0 4 0}$ & $\mathbf{0 . 0 1 6}$ \\
\hline Reliability & $\mathbf{0 . 0 3 4}$ & $\mathbf{0 . 0 1 9}$ & 0.367 \\
\hline Quality & $\mathbf{0 . 0 4 3}$ & $\mathbf{0 . 0 0 0}$ & $\mathbf{0 . 0 0 6}$ \\
\hline Guarantee & 0.231 & $\mathbf{0 . 0 0 1}$ & $\mathbf{0 . 0 3 8}$ \\
\hline Durability & 0.432 & 0.183 & 0.472 \\
\hline Functionality & $\mathbf{0 . 0 0 0}$ & $\mathbf{0 . 0 0 0}$ & $\mathbf{0 . 0 2 6}$ \\
\hline Price & 0.067 & 0.265 & $\mathbf{0 . 0 1 1}$ \\
\hline
\end{tabular}

Statistically significant differences were observed between the groups with different education levels regarding their views on quality in all of the three product types. The importance accorded to quality in laptop computers, tablet computers, and cell phones increased parallel to an increase in the level of education.

Statistically significant differences were observed between the groups with different education levels regarding their views on guarantee in laptop computers, while the differences regarding guarantee in tablet computers and cell phones were not significant. For laptop computers, 55\% of subjects from all education levels considered guarantee to be very important. For tablet computers and cell phones, a significant difference was observed between the groups with respect to guarantee. For these two types of products, the importance accorded to guarantee increased parallel to an increased in the education level.

With respect to durability, no significant differences were observed between the different education level groups. In all groups with different education levels, the ratio of subjects who considered durability to be very important in laptop computers, tablet computers and cell phones was $63 \%, 60 \%$, and $65 \%$, respectively.

Statistically significant differences were observed between the groups with different education levels regarding their views on functionality in all of the three 
product types. The importance accorded to functionality in laptop computers decreased parallel to an increase in education level; while the importance accorded to functionality in tablet computers and cell phones increased parallel to an increase in the level of education of the subjects.

With regards to price, statistically significant differences were observed between groups of different education levels regarding their views on cell phones, while the differences regarding price in laptop computers and tablet computers were not significant. It was observed that the importance accorded to cell phones increased parallel to an increase in education level. No significant difference was observed between the different education level groups with respect to the importance accorded to price for laptop computers and tablet computers. As such, $40 \%$ of subjects from all education levels described price as being very important for laptop computers, while $53 \%$ described it as being very important for laptop computers.

Level of education indirectly affects consumer's perspective in choosing and purchasing the goods or services. The higher a person's level of education, the level of consumption is even higher. Because when someone had a high level of education, they are no longer obliged to not only meet food and drinking needs but also meet the needs of information, better social interaction and also the recognition from others about their existence. Often the costs required to meet this need is far greater than the cost of meeting the needs to eat and drink. People, with high level of education, tend to be more selective in their purchases. That is because the higher a person's education level, the more needs that must be fulfilled and the higher the costs required to meet these needs, which causes consumers should choose the goods or services which must be fulfilled first . In addition, most people who have a high level of education are very concerned about the quality and price before making a purchase decision. A society with a low level of education, tend to not really concerned about quality when purchase goods or services, but they tend to look for goods or services at the lowest price so they can meet all the needs that they have. Another case with, for those whit high level of education, are usually concerned about the quality of goods or services and will compare the price with the quality obtained. That is because they also think about the long term use of goods or services (Astari and others, 2015). In our research findings we see that, except price and durability the importance of all factors increase for higher education level groups. This can be explained that, generally higher education level groups seek for more attributes in their purchasing decision of different products besides price and durability. Here we can suggest that manufacturers and retailers should also consider their costumer's level of education because of significant differences observed for different level of education of consumers.

\section{CONCLUSION}

Based on the results of the Pearson's correlation test and the chi-square test from the questionnaire study performed in Kazakhstan and Kyrgyzstan, the following observations were made:

The correlation coefficient between the laptop computer brands that first came to mind and the laptop computers that were purchased was calculated to be 0.475 , which indicated a positive, significant, and relatively high relationship between these two variables. It was thus determined that with regards to laptop computers, the participating subjects had strong and pronounced reactions based on brand perception. This 
illustrated that the brand-related activities of the relevant companies had, from their standpoint, produced the desirable results in terms of marketing. However, no significant relationship was identified between the tablet computers that first came to the mind of the study subjects and the tablet computers that were purchased.

The correlation coefficient between the cell phone brands that first came to mind and the cell phone brands that were purchased was calculated as 0.107 , which indicated a positive and significant relationship between these two variables. In cell phones, the reactions to the perception of brands were pronounced. This also illustrated that the brand-related activities of the relevant companies had produced desirable results in terms of marketing

While the level of brand awareness was high for laptop computers and cell phones, the level of brand awareness was comparatively lower for tablet computers. The reason for this might be associated with the fact that tablet computers are relatively new products, and that these electronic devices do not currently have a sufficiently wide area of use for many consumers.

In the second part of the study, the researchers statistically evaluated the relationship between the demographic characteristics of the subjects and their opinions regarding the recognition, reliability, quality, guarantee, durability, functionality, and price of brands by using the chi-square test of independence. This was performed in order to identify statistically significant relationships. The results of the tests are provided in detail in the results section, along with the relevant comments and data interpretation. According to these test results, it was determined that men generally placed greater importance on quality than women, while women were more sensitive regarding the price of products.

In this study, the researchers also determined that recognition and quality were considered to be highly important by groups of all age, and that the importance accorded to functionality gradually decreased with increasing age.

The current study also indicated that an increase in the number of children was associated with a greater importance being placed on the product price. Another observation regarding the study was that an increase in the monthly income of the study subjects led to a parallel increase in the importance they accorded to quality, durability, functionality, and confidence. However, the increase in monthly income was also determined to reduce the importance accorded to the price factor.

\section{REFERENCES}

Aaker, A. David (1996). Building Strong Brands. New York, The Free Press.

Agency on Statistics of the Republic of Kazakhstan, (2011). Almaty City Statistics Book.

Astari, Kadek Ayu Dani, Komang Santhi Arsa, Lovina Claudia Iristianty and Suhadi Riandan (2015). Analysis of Consumer Psychology Subject To Daily Time and Level of Education in Indonesia, Journal of Economics, Business and Management, Vol. 3, No. 4, pp. 470-478. 
Bertsch, Gerhard, Herwig Ostermann (2011). The Effect Of Wellness Brand Awareness On Expected And Perceived Service Quality. Tourismos: An International Multidisciplinary Journal Of Tourism Volume 6, Number 2, Autumn, pp. 103120.

Caratini, R. (1992). Dictionnariedes Nationalites et des Minorites de l'ex-URSS, References Larousse, Histoire. Paris. Gilbert, David (2003). Retail Marketing Management. Financial Times Prenticehall, Second Edition, Harlow, England.

Crimmins, J.C. (1992). Better Measurement And Management Of Brand Value. Journal Of Advertising Research. Vol.32, pp.11-19.

Gilbert, David (2003). Retail Marketing Management. Financial Times Prenticehall, Second Edition, Harlow, England.

Homburg, Christian Martin Klarmann, Jens Schmitt (2010). Brand Awareness in Business Markets: When İs İt Related To Firm Performance?, International Journal of Research in Marketing 27, pp. 201-212.

Huang, Rong ve Emine Sarigöllü (2012). How Brand Awareness Relates To Market Outcome, Brand Equity, And The Marketing Mix. Journal of Business Research 65. pp. 92-99.

Keller K. L. (2003). Strategic Brand Management: Building, Measuring, and Managing Brand Equity. 2nd Edition, New Jersey, Pearson Education Inc.

Macdonald, Emma K., Byron M. Sharp (2000). Brand Awareness Effects On Consumer Decision Making For A Common, Repeat Purchase Product:A Replication, Journal Of Business Research 48, pp. 5-15.

Madhavan, B., S. Prem Kumar (2014), Impact of Occupations of Consumers on Information Search: A Study with Reference to Car Segment, International Journal of Applied Engineering Research, Volume 9, Number 13 (2014) pp. 20792088.

Mitchell, Vincent-Wayne and Gianfranco Walsh (2004), Gender Differences in German Consumer Decision-Making Styles, Journal of Consumer Behavior, Volume 3, Issue 4, pages 331-346.

Moisescu, Ovidiu I. (2009). The Importance of Brand Awareness In Consumers' Buying Decision And Perceived Risk Assessment, Management \& Marketing Craiova 1, pp. 103-110.

Nagarkoti, Bishal (2009). Factors Influencing Consumer Behavior of Smartphone Users, Degree Thesis International Business BBA, Arcada University Finland.

Nedungadi, Prakash (1985). J. Wesley Hutchinson,"The Prototypicality of Brands: Relationships With Brand Awareness, Preference and Usage", in NA - Advances in Consumer Research Volume 12, eds. Elizabeth C. Hirschman and Moris B. Holbrook, Provo, UT : Association for Consumer Research, Pages: 498-503.

Oh, Haemoon (2000). The Effect of Brand Class, Brand Awareness, And Price On Customer Value And Behavioral Intentions, Journal Of Hospitality \& Tourism Research 2000 24, pp.136-162.

Özdamar, K. (2003). Modern Bilimsel Araştırma Yöntemleri. Eskişehir: Kaan Kitabevi. 
Reznikova, Aksana Beniaminovna (1997). "Rasiya, Turtsiya i İran v1 Sentralni Azii”, Mirovaya Ekonomika i Mejdunarodniye Atnasheniya.

Pride. WM., Ferrell OC. (1997). Marketing Conceptsandstrategies. 10th Ed. New York, Houghtonmifflin company.

Shah, Asifo (2010). Factors Affecting Consumer Behaviour. Ezine Articles. http://ezinearticles.com/?Factors-Affecting-Consumer-Behavior\&id=4602848.

Statistical Committee of the Kyrgyz Republic (2012), Annual Demographic Report of the Kyrgyz Republic.

Valkenburg, Patti M., Moniek Buijzen, (2005). Identifying Determinants of Young Children's Brand Awareness: Television, Parents, And Peers, Applied Developmental Psychology 26, pp. 456-468.

Waheed, Abdul, Syeda Shawana Mahasan and Moeed Ahmand Sandhu (2014). Factor That Affects Consumer Buying Behavior:An Analysis of Some Selected Factors, Middle-East Journal of Scientific Research 19 (5), pp.636-641.

Yakup, Durmaz and Sebastian Jablonsk (2012). Integrated Approach to Factors Affecting Consumers Purchase Behavior in Poland and an Empirical Study, Global Journal of Management and Business Research, Volume 12 Issue 15 Version 1.0, pp.60-87. 